Срібна Є. B. [1; ORCID ID: 0000-0002-6676-0606] к.е.н., старший викладач,

Ступницький В. В. ${ }^{[2 ; ~ O R C I D ~ I D: ~ 0000-0001-8845-7643], ~}$ к.е.н., доцент

${ }^{1}$ Національний університет водного господарства та природокористування, м. Рівне ${ }^{2}$ Дубенська філія вищого навчального закладу «Відкритий університет розвитку людини «Україна», м. Дубно

\title{
ТЕНДЕНЦІї ТА ПЕРСПЕКТИВИ РОЗВИТКУ ВІТЧИЗНЯНОГО АВТОМОБІЛЕБУДУВАННЯ В КОНТЕКСТІ ГЛОБАЛЬНОЇ МІЖНАРОДНОЇ полІтИкИ
}

В статті доведено, що автопромисловість $є$ одним з найважливіших сегментів світової економічної системи та економік переважної більшості держав. На сьогодні автомобілебудування є досить високим науковоємким виробництвом i автомобільна промисловість виступає однією 3 основ науково-технічного прогресу. Формування сучасного національного ринку легкових автомобілів здійснюється за рахунок досконалої державної політики уряду. Тим самим в результаті ії успішної реалізації держава щорічно забезпечує стабільні темпи економічного розвитку та гарантує високий рівень зайнятості населення країни.

Перспективи зростання виробництва автомобілів українськими підприємствами обмежені не стільки відсутністю ємного ринку, скільки відсутністю додаткових ресурсів для інвестування В збільшення потужностей. У такій ситуації розвиток автомобілебудування України безпосередньо залежить від приходу серйозних іноземних інвесторів, що принесуть у галузь не тільки капітал у фінансовій формі, але й нові технології, що так необхідні у виробництві автомобілів. За рахунок інноваційного розвитку автомобілебудування Україна зможе реалізувати конкурентоспроможну продукцію як на національному, так і на світових ринках, що забезпечить входження Украӥни в міжнародне економічне співтовариство.

Відзначено, що основною проблемою автомобільного ринку України, є те що український виробник не виробляє ті автомобілі, які могли б задовільнити споживача, тому активно розвивається імпорт автомобілів з Європи.

Зроблено висновки, що український ринок для європейських автомобільних компаній є перспективним в плані реалізації вживаних автомобілів європейських країн, тим самим забезпечується гарантований збут нових комфортних автомобілів для європейців під їхній рівень купівельної спроможності. На перспективу територія України буде придатна лише для кінцевої парковки вживаних автомобілів. 
Ключові слова: ринок автомобілебудування; виробництво автомобілів; розвиток автомобілебудування.

Українська економіка зазнала серйозної трансформації, яка призвела до реорганізації всього національного виробництва. На жаль, більшість галузей промисловості зазнали критичних змін. Серед них слід виділити українське автомобілебудування. Маючи радянський потужний виробничий комплекс, що складався практично з власної виробничої бази і включав чотири автомобільні заводи повного циклу виробництва, впродовж років політичної самостійності, ці виробничі потужності були втрачені і в цей період не можуть забезпечити власне вітчизняне виробництво автомобілів.

Політична орієнтація України на Європейський Союз призвела до відкриття внутрішнього автомобільного ринку для вживаної автомобільної техніки. Не винятком стали і легкові автомобілі. Визначились основні канали їх надходження без комплексу розтаможення - Литва та Польща.

Якраз ці два положення (втрата вітчизняного легкового авто виробництва та наповнення ринку вживаними європейськими автомобілями) визначають актуальність дослідження і дають можливість оцінити перспективи європейської співпраці з метою відродження вітчизняного автомобілебудування на принципово нових засадах.

Науковий інтерес до проблем автомобілебудування досліджується досить широко з цілою плеядою науковців. Так, проблеми вітчизняного автомобілебудування досліджують вітчизняні науковці, серед яких слід виділити таких вчених, як Антонюк О. І., Рифяк Р. Р., Савич О. П., Мовчаренко В. В., Пасько А. В., Семененко Т. М., Бодрова Н. Е., Проноза П. В., Ладуба Т. Ю., Шевченко В. А., Онищенко В. П. та інші.

Мета дослідження - аналіз тенденцій в вітчизняному автомобілебудуванні для ефективної адаптації українського автопрому згідно з новими ми вимірами та вимогами, а також надання рекомендацій щодо подальшого розвитку даної галузі. Відповідно до мети визначені наступні завдання:

- оцінити тенденції та зміни в світовому автомобілебудуванні;

- дослідити динамічні зміни в реалізації вітчизняних автомобілів;

- визначити перспективи європейської співпраці в автокомплексі для українських виробників і споживачів.

Сучасне автомобілебудування формує економіку країни, адже вимагає застосування сучасних матеріалів та хімічних елементів, 
використовує програмне забезпечення як у виробництві автомобілів, так і в їх експлуатації. Згідно маркетингового підходу, купівельна спроможність $€$ визначальним чинником функціонування ринку легкових автомобілів, наприклад розвиток виробництва автомобілів компанії Форд, коли компанія запропонувала бюджетний варіант автомобілів для середнього класу США.

Так, стабільна економічна ситуація країни забезпечує стрімкий розвиток виробництва та реалізації автомобілів. Це наглядно прослідковується в США, країнах ЄС, країнах Азії (Корея, Японія, Китай). Проте, як в розвинутих країнах, так і в країнах, що розвиваються, автомобільний ринок формується за рахунок двох сегментів: первинного та вторинного. Однак, для розвинених країн співвідношення між первинним і вторинним ринком значно відрізняється ніж у країнах, що розвиваються. Для України вторинний ринок має мінімальну залежність від кредитування та купівельної спроможності українців, і в період економічних спадів країни він починає домінувати.

Слід відзначити загальну тенденцію для розвинутих країн, що левова частка припадає лише на національні автомобілі. Менш розвинені країни намагаються стимулювати власне виробництво за рахунок введення митного збору на поставки як нових, так і вживаних іноземних авто. Так, Чехія, Словаччина, Румунія утримали власне вітчизняне виробництво легкових автомобілів. Це забезпечує найбільшу частку формування їх національного ВВП, тобто в цих країнах виробництво автомобілів складає понад 100 авто на 1000 жителів, тим самим забезпечує попит в межах своєї країни і повноцінно формує експорт власних автомобілів.

Якщо розглядати Україну, то слід виділити два періоди в розрізі автомобілебудування. До 1991 р., коли український автопром визначався чотирма великими автомобільними заводами:

- легкове автомобілебудування було представлено Запорізьким і Луцьким автозаводом, річна проєктна потужність складала 300-350 тис. шт. та 17 тис. шт. відповідно;

- вантажне автомобілебудування формувалося Кременчуцьким автозаводом потужністю 35 тис. шт. щорічно;

- автобусне автомобілебудування було сформоване Львівським автобусним заводом, потужністю 16 тис. автобусів в рік.

Ці чотири заводи обслуговували понад 60 підприємств України та понад 300 підприємств різних галузей СРСР. Найбільший обсяг випуску автомобілів був досягнутий у 1985 р. Так, АвтоЗАЗ випустив близько 160 тис. автомобілів, ЛуАЗ понад 10 тис., КрАЗ понад 30 тис. 
і ЛАЗ понад 15 тис. автобусів.

При проголошенні суверенітету, в Україні починають формуватися нові форми автомобілебудування - складальні заводи, серед них відзначено Черкаси, що освоїли складання автобусів «Богдан», а в Сімферополі та Лубнах - складання автобусів «Газель». Відповідне складання було налагоджене в Борисполі та Чернігові. В Іллічівську налагодили складання «Волга», а в Ужгороді відкрили завод по збору автомобілів марки «Skoda» та «Audi». В 2008 році було відкрито завод Богдан із виробництва легкових автомобілів у Черкасах.

Відповідно період 2000-2008 рр. - це період активного впровадження зборочних форм автомобілів найбільших сусідів Росії, Чехії, Німеччини. При цьому власний вітчизняний автомобілебудівний комплекс був ліквідований. Тому український ринок заполонили іноземні марки автомобілів. Власне автомобілебудування не спроможне конкурувати 3 японськими, корейськими, німецькими автовиробниками. В такій ситуації (ліквідації власного виробництва через економічні пріоритети) в Україну хлинули автомобілі європейських країн. Цей процес уряд країни почав регулювати через впровадження різних податкових та митних зборів. Відповідно вводиться збір за митне оформлення ввезеного авто, а також накладається мито, впроваджується так званих утилізаційний збір, для юридичних осіб додатково впроваджується ПДВ та акцизний збір на ввезені автомобілі. Відповідно кінцева вартість придбання автомобілів різко зростає за рахунок цих впроваджень. На даний період на ввезений автомобіль діє 20\% НДС та $10 \%$ мита, при цьому введено ряд акцизів. Це формує постійне джерело корупційного збагачення, як митниками, так і податківцями. При відміні усіх діючих акцизів, за ввезений автомобіль прийдеться платити понад $30 \%$ придбаного автомобіля.

Пропозиції щодо ліквідації такого стабільного корупційного механізму через введення 5\% від обсягу проданих автомобілів урядом та владою України відхиляються. Адже втрачається потенційне джерело збагачення для окремих корупційних бізнесових формувань, які досить тісно «співпрацюють» з урядом та лобіюють його.

Єдиним позитивним елементом у системі державного регулювання імпорту іноземних автомобілів $\epsilon$ впровадження нульової ставки на ввезені електромобілі [1]. Проте вартість їх надзвичайно висока, і частка в загальному обсязі залишається досить низькою. Ці електромобілі по купівельній спроможності 
українців являються досить дорогими. На даний період вони використовуються як інвестиції бізнесменів у розвиток вітчизняного таксопарку.

Для країн ЄС ввезення іноземних автомобілів - це процес чітко нормативно врегульований із визначенням конкретних митних пільг певним категоріям населення [2]. Для України такі митні пільги проявляються для інвалідів групи та електромобілі.

Така неоднозначна урядова політика щодо митного регулювання ввезення автомобілів, спричиняє в Україні пошук шляхів зменшення кінцевої вартості придбання ввезених автомобілів. Серед них виділяється схема транзитного та тимчасового ввезення. Так, в 2017 р. з усіх ввезених 958,5 тис. іноземних транспортних засобів за схемою транзиту було ввезено 209,6 тис. автомобілів, а за схемою тимчасового ввезення - 748,9 тис. автомобілів. Ці автомобілі надходили з Польщі, Литви, Німеччини, Болгарії та Чехії. Тому з 2015 по 2017 рр. український ринок легкових автомобілів показує позитивну динаміку росту. Так, в 2016 році він зростає на 36\%, а в 2017 році - на 69\% за рахунок вживаних автомобілів.

Ситуація 2019 року, коли були прийняті так звані закони про «євробляхи», призвела до зменшення купівлі не розмитнених автомобілів, Так, у порівнянні з продажем 154,5 тис. автомобілів не розмитнених було реалізовано лише 21 тис. Найбільше купують українці на вживаному ринку моделі ВАЗ та Volkswagen.

Обсяг виробництва автомобілів впродовж 2011-2018 подано в табл. 1.

Таблиця 1

Виробництво автомобілів в Україні у 2011-2018 рр., тис. од.

\begin{tabular}{|l|l|l|l|l|l|l|l|l|}
\hline \multirow{2}{*}{ Автомобілі } & \multicolumn{7}{|c|}{ Роки } \\
\cline { 2 - 9 } & 2011 & 2012 & 2013 & 2014 & 2015 & 2016 & 2017 & 2018 \\
\hline Легкові & 97,585 & 69,687 & 45,758 & 25,941 & 5,654 & 4,340 & 7,296 & 5,660 \\
\hline $\begin{array}{l}\text { Комерційні } \\
\text { (вантажні) }\end{array}$ & 3,331 & 3,235 & 2,193 & 1,932 & 1,735 & 0,603 & 0,486 & 0,132 \\
\hline Усього & 100,916 & 72,922 & 47,951 & 27,873 & 7,389 & 4,943 & 7,782 & 5,792 \\
\hline
\end{tabular}

Статистика відзначає, що з кожним роком обсяг виробництва українських автомобілів постійно скорочується. 2017 рік став роком, коли обсяг виробництва автомобілів зріс у 1,5 рази у порівнянні 3 попереднім роком. Це було зумовлено реалізацією державної підтримки вітчизняного автомобілебудування за рахунок залучення іноземних інвестицій від корейської корпорації «Daewoo». 
Починаючи з 2018, року українське виробництво автомобілів різко скорочується. У 2019 році в Україні залишився єдиний діючий автомобільний виробник (здійснює великовузлову зборку) «Єврокар», який збирає автомобілі марки «Skoda» (табл. 2) [3].

Таблиця 2

Вітчизняні обсяги виробництва автомобілів у 2019 р.

\begin{tabular}{|c|c|c|c|c|c|c|c|}
\hline Виробники & Skoda & БАЗ & 3АЗ & Богдан & КрАЗ & $\begin{array}{c}\text { Вантажні } \\
\text { автомобілі, } \\
\text { спецтехніка }\end{array}$ & Всього \\
\hline $\begin{array}{c}\text { Обсяги } \\
\text { виробництва, } \\
\text { шт. }\end{array}$ & 5381 & 173 & 74 & 68 & - & 500 & 6196 \\
\hline
\end{tabular}

Таке падіння виробництва власних автомобілів зумовлено наступними наслідками:

1. В політичному плані - військове протистояння Росії за рахунок втрати Криму та Донбасу.

2. У фінансовому плані - наслідки фінансової кризи 2008 р., коли різко впала купівельна спроможність українців та припинилось кредитування фізичних осіб, що спричинило переорієнтацію значної частки покупців автомобілів 3 нових на вживані. Фактично був ліквідованих бюджетний сегмент вітчизняного авто українського виробництва.

3. Торговий чинник - укладання угоди про зону вільної торгівлі з ЄС, що призвело до впровадження екологічних стандартів Євро-5. Тому в Україні припинили зборку корейських та китайських автомобілів, що не відповідали екологічним вимогам.

Загалом всі чинники спричинили масове використання вживаних європейських автомобілів з іноземною реєстрацією, а це водночас витіснило українські моделі 3 автомобільного ринку. Відповідно уряд змушений легалізувати такий бізнес і при цьому хоч частково наповнити український бюджет. Тому на українських ринках масово продаються автомобілі з іноземною реєстрацією.

Характерною особливістю українського ринку автомобілів $\epsilon$ вік експлуатації автомобілів (рис. 1) [4]. Такий стан ринку зумовлений купівельною неспроможністю населення України, яке вимушене звертатись на вторинний авторинок. А це означає, що на макрорівні економічна політика уряду абсолютно невідпрацьована, а відтак Україна втратила власне автомобілебудування, незважаючи на попит воєнних автомобілів через російсько-український конфлікт на Донбасі. 


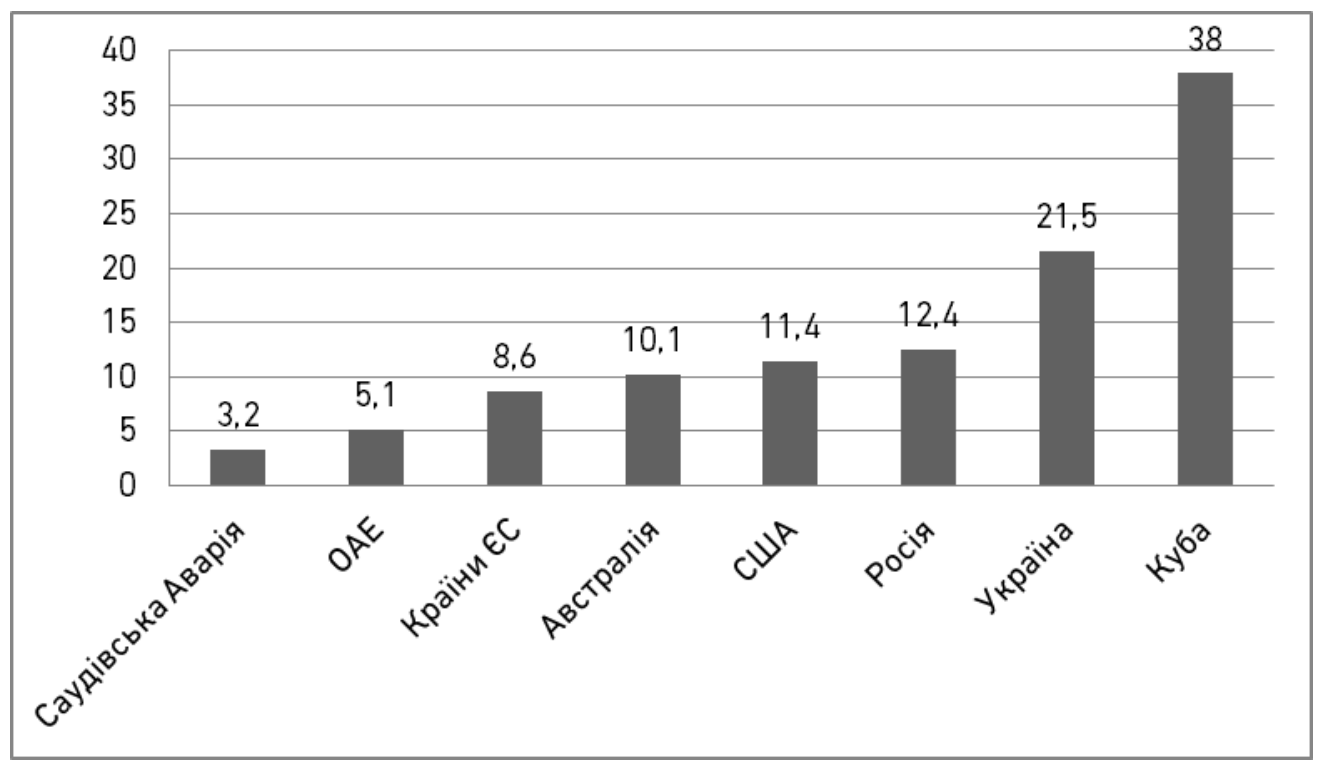

Рис. 1. Середній вік автомобілів в різних країнах, роки

В країнах ЄC відзначається тенденція на зростання попиту на комерційні автомобілі [5], то в Україні ці тенденції не прослідковуються. Проте внутрішній автомобільний ринок України залишається недостатньо насиченим і має потенційну місткість (рис. 2).

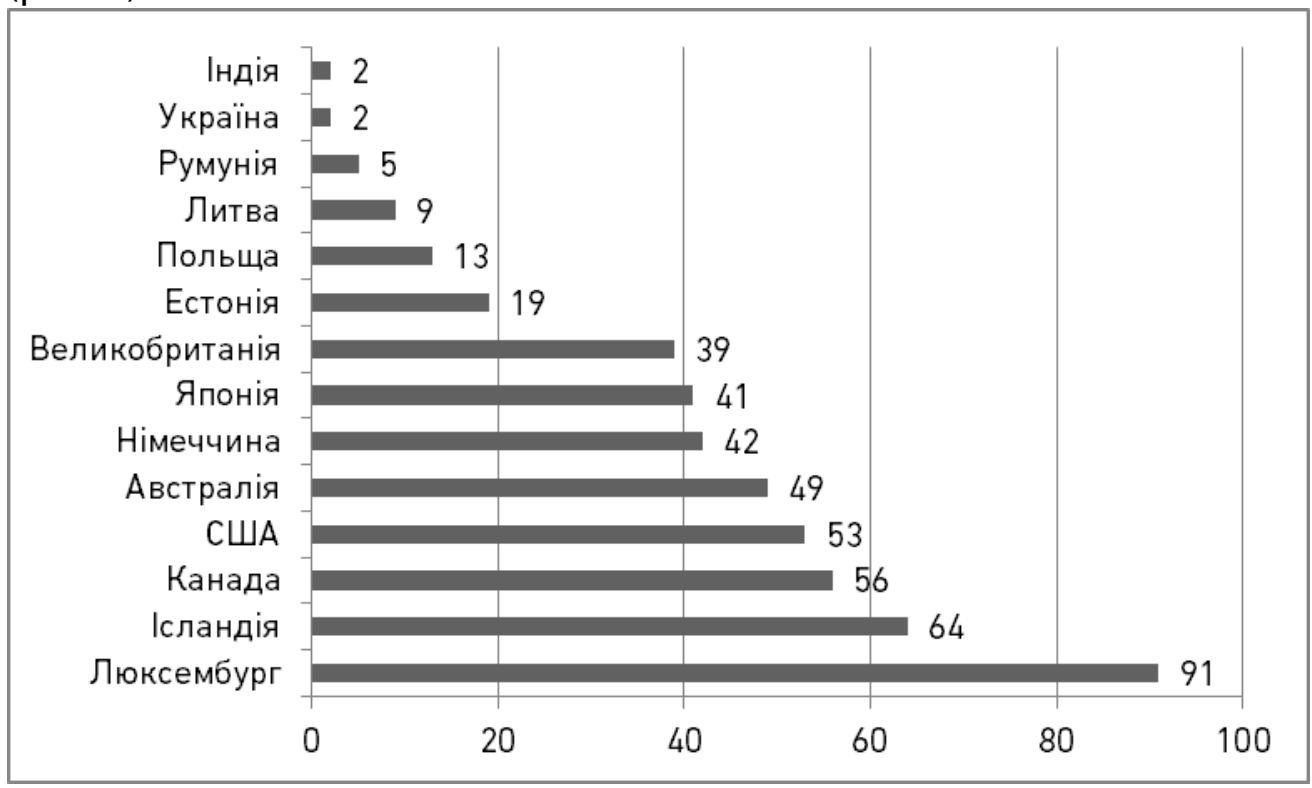

Рис. 2. Кількість автомобілів на 1000 осіб населення 
Рис. 2 свідчить, що Україна 3 потужного автовиробника перетворилась в додатковий сегмент європейських країн щодо утилізації вживаних автомобілів. Іншими словами, територія України стала зоною гарантованої реалізації вживаних європейських автомобілів. Враховуючи різкі кліматичні зміни (підтоплення, затоплення, урагани, буревії тощо), кількість європейських постраждалих автомобілів різко зростає. Відповідно ці автомобілі реалізовуються в Україні, а європейські виробники за рахунок національних урядових програм забезпечують відносно стійкі об'єми виробництва та реалізації нових національних автомобілів.

На період початку 2020 року у світі вироблено приблизно 10 млрд автомобілів. Враховуючи, що кількість населення Землі біля 7,7 млрд осіб, то математично виходить, що кожен житель Землі має особисте авто.

Проте дійсність зовсім інша. Так, зростаючий попит на автомобілі престижного класу прослідковується лише для сегменту забезпечених осіб. Обсяг продажу цього сегменту за останні 2 роки зріс на $80 \%$ за рахунок реалізації наступних моделей McLaren, Zonda, BMW, Ferrari, Porsche, Mercedes, Maybach, Rolls-Royce тощо. Водночас інші сегменти продажів автомобілів скорочуються. Адже для американського та європейського ринку характерна ситуація, коли сім'я забезпечена щонайменше одним автомобілем, а то й двома. Дослідження в Україні вказали, що 84\% із 31000 опитаних не можуть придбати новий автомобіль. Таким чином, це вказує на дві основні тенденції. По-перше, у пересічного населення низька купівельна спроможність. По-друге, в автомобільній індустрії існує надвиробництво, яке в наукових дослідженнях абсолютно не висвітлено та проаналізовано. Відповідно всі автомобільні ТНК мають нереалізовані запаси автомобілів, що 3 кожним роком збільшуються. Це виявляється у масштабних паркових стоянках нових непроданих автомобілів у всьому світі. Цими автомобілями зайняті території злітних смуг закинутих авіабаз, старих доків, терміналів, а то й земельних ділянок біля автозаводів.

Відповідно для реалізації нових автомобілів необхідно автовиробникам заохочувати споживачів у заміні своїх автомобілів. Для цього Німеччина впроваджувала державну компенсацію при придбанні нового автомобіля. При цьому виникає нова загроза, яка призводить до вирішення проблеми утилізації відносно нових автомобілів. Для країн Європи стала діяти відпрацьована схема реалізації цих автомобілів через окремі країни, зокрема Литву та Польщу. Дані авто реалізуються переважно в Україну та європейську 
частину Росії.

Така ситуація спричинила фактичне припинення виробництва вітчизняних автомобілів та ліквідацію крупновузлової зборки російських та корейських автомобілів в Україні. Тобто український ринок для європейських автомобільних компаній є перспективним в плані реалізації вживаних автомобілів європейських країн, тим самим забезпечується гарантований збут нових комфортних автомобілів для європейців під їхній рівень купівельної спроможності. На перспективу територія України буде придатна лише для кінцевої парковки вживаних автомобілів. Досить цікава позиція сучасного українського уряду, яка відкриває реальні можливості для переміщення вживаних автомобілів в Україну, цим самим негласно погоджуючись на повну ліквідацію власного автопрому. В глобальному плані впродовж 28 років в Україні реалізований план ліквідації потужного авто промислового комплексу. При продовженні таких стратегічних реформувань української економіки, відродження вітчизняного автобудування не відбудеться.

Таким чином, світове автомобілебудування в умовах економіко-фінансового безладу (за рахунок впровадження світових карантинних заходів) призвело до низки взаємопов'язаних викликів і жорстких вимог безпеки, економічності та екологічності легкового авто. А це приводить до корпоративного управління автовиробниками зберігати поточний стан перевиробництва, стабільні параметри фінансової стійкості, удержання напрацьованих пропорцій в автомобілебудуванні.

Однозначно, всі автомобільні корпорації в певній мірі відчули вплив глобальних економічних перетворень і тим самим зазнали впливу. Проте цей вплив носить чітке вираження регіональних параметрів результативності їх функціонування.

Щодо вітчизняного автомобілебудування, то загальна характеристика відзначає стабільну тенденцію до припинення власного виробництва автомобілів. Відповідно 3 чотирьох автомобільних компаній в Україні працює лише крупновузлова зборка чеського виробника «Skoda», що забезпечує 530 автомобілів щорічно. Дана ситуація стала наслідком припинення державного регулювання вітчизняного автомобілебудування.

Щодо реалізації автомобілів на українському ринку, динаміка відзначає значні зростання продажів. Це зумовлено реалізацією вживаних авто через налагоджені канали збуту з Польщі та Литви. В глобальному масштабі така ситуація стала наслідком світового 
перевиробництва авто. Автомобільні гіганти, щоб утримати рівень прибутковості, вимушені накопичувати запаси випущених автомобілів з одного боку, а з іншого - спонукати споживачів до придбання нових, при цьому реалізовувати свої вживані. В цьому контексті, Україна стала ринком реалізації таких автомобілів. Українська влада при цьому спромоглася лише частково поповнювати бюджет за рахунок розмитнення таких автомобілів. Отже, втрата власного автомобілебудування $\epsilon$ результатом відсутності вітчизняної національної промислової політики, яка стала заручницею втрати національного суверенітету України. Тому в майбутньому прогнозуванні при відсутності політичного суверенітету України говорити про відродження вітчизняного автопрому не приходиться.

Розглядаючи українське автомобілебудування в період 19802020 рр. спостерігається чітка глобальна закономірність перетворення країни-виробника в країну гарантованого споживача відпрацьованих автомобілів. При цьому позитивно вирішуються економічні цілі європейського автомобільного корпоративного управління за рахунок ліквідації вітчизняного автомобільного виробництва.

1. Сотніченко О.А. Митне регулювання товарообороту у контексті міжнародної інтеграції. Збірник наукових праць Національного університету державної податкової служби України. 2013. № 2. С. 165-176. 2. Ввезення автотранспорту на територію країн Європейського союзу URL: http://www.sng-producer.ru/company/bqth/ (дата звернення: 22.05.2020). 3. УкрАвтопром. Ассоциация автопроизводителей Украины: Статистика. URL: http://ukrautoprom.com.ua (дата звернення: 22.05.2020). 4. Кищун В. А. Виробництво легкових автомобілів: світові та вітчизняні тенденції. Луцький національний технічний університет : зб. наук. пр. 2016. № 13. С. 137-145. 5. European Automobile Manufacturers' Association, Trade Statistics. URL: http://www.acea.be/index.php/news/news_detail/trade/ (Accessed: 22.05.2020).

\section{REFERENCES:}

1. Sotnichenko 0 . A. Mytne rehuliuvannia tovarooborotu u konteksti mizhnarodnoi intehratsii. Zbirnyk naukovykh prats Natsionalnoho universytetu derzhavnoi podatkovoi sluzhby Ukrainy. 2013. № 2. S. 165-176. 2. Vvezennia avtotransportu na terytoriiu krain Yevropeiskoho soiuzu URL: http://www.sng-producer.ru/company/bqth/ (data zvernennia: 22.05.2020). 3. UkrAvtoprom. Assotsiatsiya avtoproizvoditeley Ukrainyi: Statistika. URL: http://ukrautoprom.com.ua (data zvernennia: 22.05.2020). 4. Kyshchun V. A. Vyrobnytstvo lehkovykh avtomobiliv: svitovi ta vitchyzniani tendentsii. Lutskyi natsionalnyi tekhnichnyi universytet : zb. nauk. pr. 2016. № 13. S. 137-145. 5. European Automobile Manufacturers Association, Trade Statistics. URL: http://www.acea.be/index.php/news/news_detail/trade/ (Accessed: 22.05.2020). 
Sribna Y. V. [1; ORCID ID: 0000-0002-6676-0606],

Candidate of Economics (Ph.D.), Senior Lecturer,

Stupnytskyi V. V. [2; ORCID ID: 0000-0001-8845-7643],

Candidate of Economics (Ph.D.), Associate Professor

${ }^{1}$ National University of Water and Environmental Engineering, Rivne

${ }^{2}$ Dubno Branch of Higher Education Institution «Open International University of Human

Development «Ukraine», Dubno

\section{TRENDS AND PROSPECTS FOR THE DEVELOPMENT OF DOMESTIC AUTOMOTIVE IN THE CONTEXT OF GLOBAL INTERNATIONAL POLICY}

The article proves that the automotive industry is one of the most important segments of the world economic system and the economies of the vast majority of countries. Today, the automotive industry is a fairly high science-intensive production and the automotive industry is one of the foundations of scientific and technological progress. The formation of the modern national car market is carried out at the expense of the perfect state policy of the government. Thus, as a result of its successful implementation, the state annually ensures a stable pace of economic development and guarantees a high level of employment.

Prospects for growth in car production by Ukrainian enterprises are limited not so much by the lack of a capacious market, but by the lack of additional resources to invest in increasing capacity. In this situation, the development of Ukraine's automotive industry directly depends on the arrival of serious foreign investors, who will bring to the industry not only capital in financial form, but also new technologies that are so necessary in the production of cars. Due to the innovative development of the automotive industry, Ukraine will be able to sell competitive products in both national and world markets, which will ensure Ukraine's entry into the international economic community.

It is noted that the main problem of the car market of Ukraine is that the Ukrainian manufacturer does not produce those cars that could satisfy the consumer, so the import of cars from Europe is actively developing. It is concluded that the Ukrainian market for European car companies is promising in terms of sales of used cars of European countries, thus ensuring the guaranteed sale of new comfortable cars for Europeans at their level of purchasing power. In the future, the territory of Ukraine will be suitable only for the final parking of used cars.

Keywords: automotive market; car production; automotive development. 


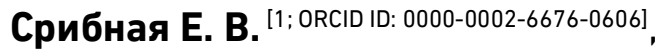

к.э.Н., ст. преподаватель

Ступницкий В. В. ${ }^{[2 ; ~ O R C I D ~ I D: ~ 0000-0001-8845-7643], ~}$ к.э.н., доцент

${ }^{1}$ Национальный университет водного хозяйства и природопользования, г. Ровно

${ }^{2}$ Дубенский филиал высшего учебного заведения «Открытый международный университет развития человека» Украина», г. Дубно

\section{ТЕНДЕНЦИИ И ПЕРСПЕКТИВЫ РАЗВИТИЯ ОТЕЧЕСТВЕННОГО АВТОМОБИЛЕСТРОЕНИЯ В КОНТЕКСТЕ ГЛОБАЛЬНОЙ МЕЖДУНАРОДНОЙ ПОЛИТИКИ}

В статье доказано, что автопромышленность является одним из важнейших сегментов мировой экономической системы и экономик подавляющего большинства государств. Автомобилестроение является достаточно высоким наукоемким производством и автомобильная промышленность выступает одной из основ научно-технического прогресса. Формирование современного национального рынка легковых автомобилей осуществляется за счет совершенной государственной политики правительства. Тем самым в результате ее успешной реализации государство ежегодно обеспечивает стабильные темпы экономического развития и гарантирует высокий уровень занятости населения страны.

Перспективы роста производства автомобилей украинскими предприятиями стеснены не столько отсутствием емкого рынка, сколько отсутствием дополнительных ресурсов для инвестирования в увеличение мощностей. В такой ситуации развитие автомобилестроения Украины напрямую зависит от прихода серьезных иностранных инвесторов, которые принесут в отрасль не только капитал в финансовой форме, но и новые технологии.

Отмечено, что основной проблемой автомобильного рынка Украины, является то, что украинский производитель не производит те автомобили, которые могли бы удовлетворить потребителя, поэтому активно развивается импорт автомобилей из Европы. Украинский рынок для европейских автомобильных компаний является перспективным в плане реализации бывших в употреблении автомобилей, тем самым обеспечивается гарантированный сбыт новых комфортных автомобилей для европейцев под их уровень покупательной способности. В перспективе территория Украины будет пригодна только для конечной парковки автомобилей.

Ключевые слова: рынок автомобилестроения; производство автомобилей; развитие автомобилестроения. 